\title{
ケミカルタンカーの転覆・沈没事故の事例解析と再発防止
}

\author{
黒田 貴子 ${ }^{1}$ ・庄司 邦昭 ${ }^{2}$-田口 晴邦 ${ }^{3}$ ・田村 兼吉 ${ }^{1}$
}

\section{Analysis and Remarks for Prevention of Recurrence on the Capsizing and Sinking Accident of a Chemical Tanker}

\author{
Takako KURODA, Kuniaki SHOJI, \\ Harukuni TAGUCHI and Kenkichi TAMURA
}

\begin{abstract}
The present paper describes an example analysis and recurrence prevention of capsizing and sinking accident of a chemical tanker which occurred off Niigata Sado Island in January, 2011. In this accident, heel angle of the chemical tanker running in quartering sea from port side became large, and finally the chemical tanker capsized and sank. Authors analyzed the situation of the chemical tanker during accident. The cause of this accident is sea water flooded to the ballast tank by the defect of the flood prevention function of the air pipe. Firstly, steady heel occurred because the shipping water stagnated on the upper deck and expansion trunk of the chemical tanker, and it was also flooded to the ballast tank due to the defect of the air pipe. A repetition of these phenomena increased the heel angle and caused capsizing and sinking. Based on this analysis result, Japan Transport Safety Board proposed to the minister of Land, Infrastructure, Transport and Tourism that the air pipe head must be serviced regularly.
\end{abstract}

Keywords : Accident analysis, Chemical Tanker, Capsizing, Sinking, Air pipe キーワード: 事故解析, ケミカルタンカー, 転覆, 沈没, 空気管

\section{1. 緒言}

平成 24 年度までの過去 5 年間の海上保安統計年 報救難統計の要救助海難種類別統計によると、毎年 1800 件以上の要救助海難に対して転覆によるもの は約 100 隻前後であり、転覆事故の件数は毎年ほぼ 同じである。このような事故を減らすには事故の解 析と、解析結果に基づく再発防止の提言が不可欠で ある。

海上技術安全研究所では、運輸安全委員会より船 舶事故原因の解析等の一部の委託を受けて事故解析 を実施しており、解析結果は再発防止等に活かされ

\section{ている。}

本論文では、その海難事故の解析事例として、平 成 23 年 1 月に新潟県佐渡島南西方沖で発生したケミ カルタンカーの転覆・沈没事故 ${ }^{(1)}$ を取り上げ、事故 発生時の転覆に至る大傾斜を引き起こした状況を解 析した結果と、結果に基づいて実施された再発防止 について述べる。

\section{2. 事故の概要と経過}

解析した海難事故の概要と事故の経過について以 下に述べる。

\footnotetext{
正会員 海上技術安全研究所（干181-0004 東京都三鷹市新川 6 丁目 38 番 1 号)

名誉会員 運輸安全委員会（テ100-8918 東京都千代田区霞が関 2-1-2）

非会員 海上技術安全研究所
} 


\section{1 事故の概要}

ケミカルタンカーS 号は船長ほか 4 名が乗り込み、 䣷酸ビニルモノマー約 $1,000 \mathrm{t}$ を積載し、大分県大 分空港沖から石川県珠洲市 (能登半島) 禄剛埼沖を 経て新潟県佐渡市（佐渡島）赤泊港に向けて東北東 進中に転覆し、平成 23 年 1 月 9 日 9 時 22 分頃沈没 した。乗組員の内、機関長が死亡し、船長が行方不 明になった。

\section{2 事故の経過}

本事故が発生するまでの経過を以下に示す。また、 事故の経過地点を図 1 に示寸。

（1）地点 I 1 月 9 日 2 時 20 分ごろ

波高約 2.5 3. $0 \mathrm{~m}$ の追い波と西方から風速約 $20 \mathrm{~m} / \mathrm{s}$ の風を受けながら船速約 $11.0 \mathrm{kn}$ で航行中、左 舷側約 2 deg. $\sim 7 \mathrm{deg}$.の範囲で横摇れを繰り返して いた。

（2）地点 II 1 月 9 日 4 時 00 分ごろ

左斜め後方約 $40 \mathrm{deg}$. から波高約 $2.5 \mathrm{~m}$ の波と西方 から風速約 $12 \mathrm{~m} / \mathrm{s}$ の風を受けながら船速約 $9.8 \mathrm{kn}$ で 航行中、右舷側に約 5 deg. 〜左舷側 $20 \mathrm{deg}$. の範囲で 横摇れをしていた。また、左舷膨張トランク上が左 斜め後方からの波に洗われ、左舷バラストタンクの 空気管の管頭金物（以後、空気管頭）が海水を被っ ていることを認めた。 $\mathrm{S}$ 号は平成 22 年 11 月の同航 路の航海において、バラストタンクに海水が流入し た事例があったことから、バラスト水の排水を試み たが、船尾楼甲板前方左舷側に設けられたポンプル 一ムの出入りロハッチが海水に没していたため、排 水を断念した。さらに燃料サービスタンクに海水が 浸水していることを認めた。

（3）地点III 1 月 9 日 6 時 10 分ごろ

船体が左舷側に約 $25 \mathrm{deg}$. 傾斜していることを海 上保安庁に連絡し、救助を要請した。

(4) 地点IV

6 時 30 分ごろに主機が停止し、7 時 5 分ごろ左舷 側一の傾斜が約 $50 \mathrm{deg}$. 以上になり、まもなく転覆し た。その後 9 時 22 分頃に沈没した。

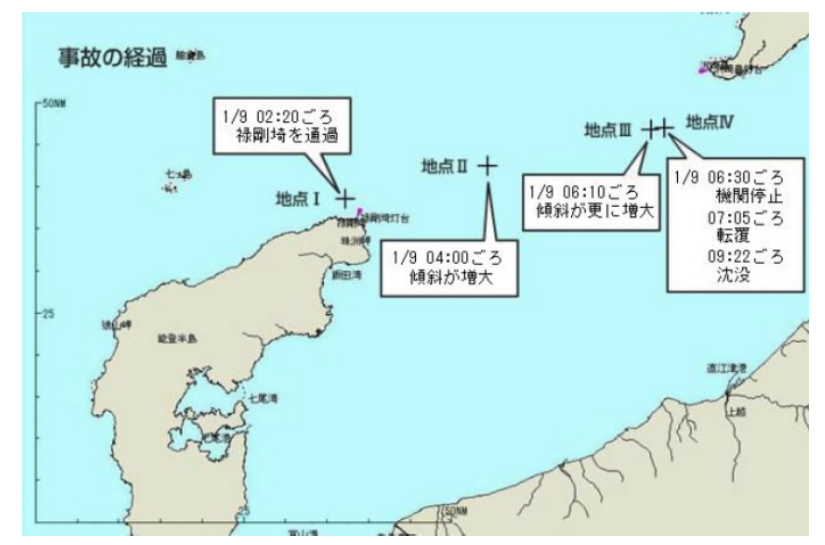

図 1 事故の経過地点

\section{3. 事故解析}

$\mathrm{S}$ 号の事故発生時の復原力及び当時の海象条件下 での船体運動と船体姿勢を推定し、転覆・沈没の可 能性について検討した。

\section{1 事故解析対象船}

$\mathrm{S}$ 号の主要目を表 1 に、一般配置図を図 2 に、中 央横断面図を図 3 に示寸。 $\mathrm{S}$ 号は貨物タンクの側面 及び底面をバラストタンクで囲まれた二重船殼構造 で、貨物タンクの上には澎張トランクを有している。 膨張トランク及び上甲板上は強度部材によって水が 滞留しやすい構造になっている。バラストタンクの 空気管頭は上甲板上に、燃料サービスタンクの空気 管頭は船尾楼甲板上にある。

表 $1 \quad \mathrm{~S}$ 号の主要目

\begin{tabular}{|c|c|}
\hline 総トン数 & 499 トン \\
\hline 全長 & $64.80 \mathrm{~m}$ \\
\hline 型幅 & $10.00 \mathrm{~m}$ \\
\hline 型深さ & $4.50 \mathrm{~m}$ \\
\hline
\end{tabular}

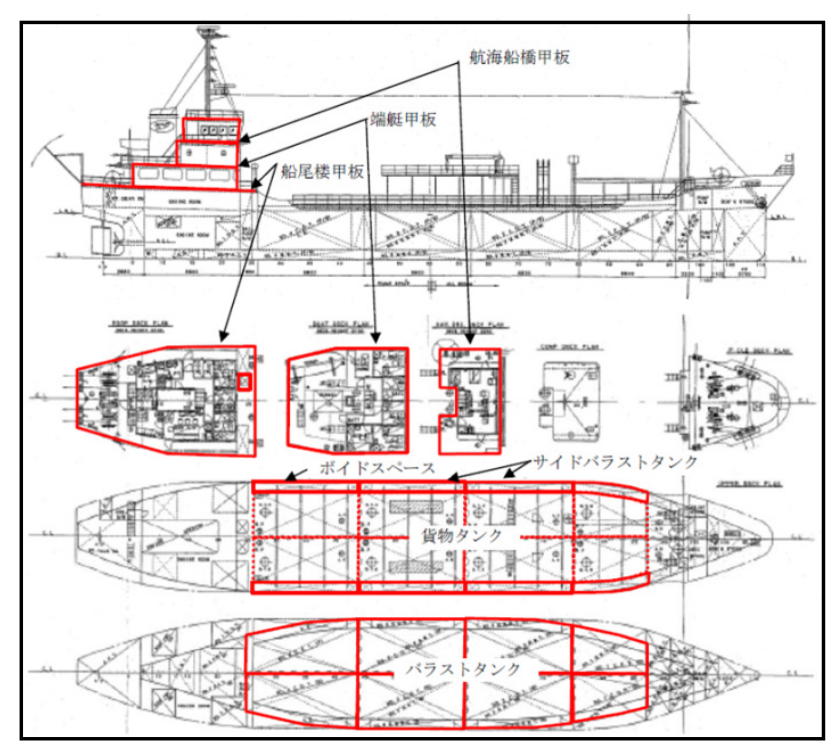

図 2 S 号の一般配置図 


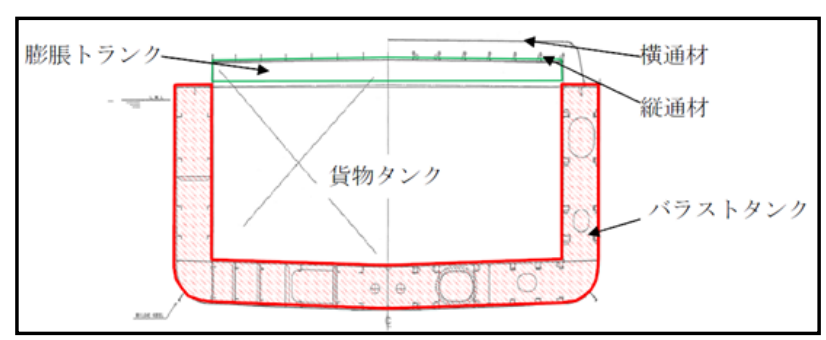

図 $3 \mathrm{~S}$ 号の中央横断面図

\section{2 事故発生時の気象・海象}

事故発生時の対象海域での気象及び海象は、一般 財団法人日本気象協会の日本沿岸局地波浪推算デー タベースを用いて推定した。推定日は 2011 年 1 月 9 日、時間と地点は(1) 2 時 20 分に禄剛埼を通過した地 点、(2) 4 時 00 分に $\mathrm{S}$ 号の傾斜が増大した地点、(3) 4 時 00 分と沈没する 7 時 00 分の間の 5 時 30 分の地点、 (4)7 時 00 分に S 号が沈没した地点の各地点で時間を 内挿して求めた。表 2 に推定した気象・海象の推定 值を示す。事故発生時の波は西北西から波高 $2 \sim 3 \mathrm{~m}$ 、 風速は西から 12～13m/s である。

表 2 事故発生時の気象・海象の推定值

\begin{tabular}{|c|c|c|c|c|c|}
\hline 番号 & 波高 & 波周期 & 波向 & 風速 & 風向 \\
\cline { 2 - 6 } & $(\mathrm{m})$ & $(\mathrm{sec})$ & $(\mathrm{deg})$. & $(\mathrm{m} / \mathrm{s})$ & $(\mathrm{deg})$. \\
\hline (1) & 2.22 & 5.3 & 288 & 13.0 & 268 \\
\hline (2) & 2.66 & 7.2 & 293 & 12.8 & 274 \\
\hline (3) & 2.79 & 7.4 & 293 & 12.8 & 279 \\
\hline (4) & 2.95 & 7.3 & 285 & 12.3 & 285 \\
\hline
\end{tabular}

\section{3 事故発生当時の復原力}

出港時の喫水、貨物の積載状況及び出港時の燃料 油量から事故発生時の排水量を 1751.55 七 と推定し、 その時の復原力を計算した結果を図 4 に示す。図中、 実線は自由水影響を考慮した場合、破線は自由水影 響を無視した場合である。船舶復原性規則にある $30 \mathrm{deg}$. 以上の横傾斜角において、0. $2 \mathrm{~m}$ 以上の復原て こを有することとする規定に対し、横傾斜角 $30 \mathrm{deg}$. の時の復原てこは $0.19 \mathrm{~m}$ となり、 $0.01 \mathrm{~m}$ 下回ること が分かる。

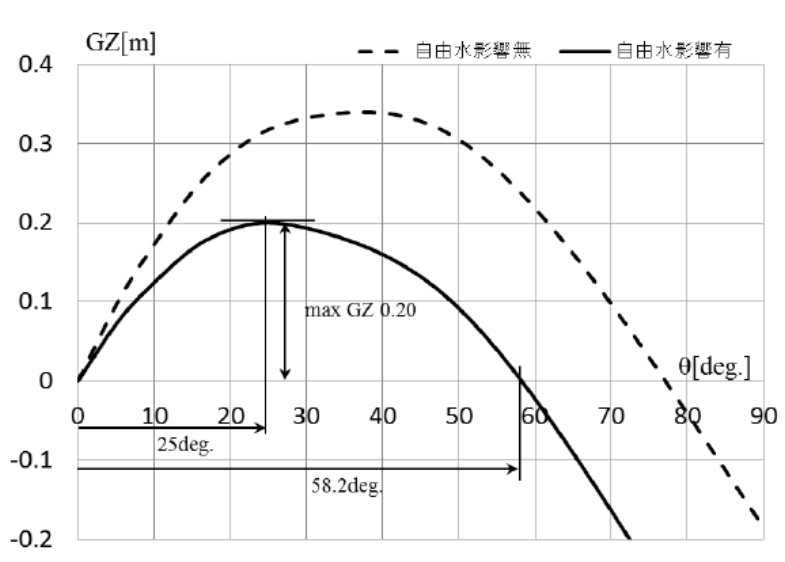

図 4 事故発生時の復原力曲線

\section{4 風による横傾斜角}

$\mathrm{S}$ 号の風による横傾斜角を計算した。風圧面積は 船長の為の復原性資料で用いられた船体の風圧面積 に、甲板上の艤装品等の側面投影面積を加え、作用 する風圧力は成分分離型モデルによる藤原の式 (2) を用いて計算した。その結果、船舶安全法の規定で 復原性計算に用いられる風速 $26 \mathrm{~m} / \mathrm{s}$ において横傾斜 角は約 $0.7 \mathrm{deg}$. であった。よって風による横傾斜は ほとんど発生しないということが分かる。

\section{5 波浪中の船体運動}

事故の経過によると S 号は徐々に左舷側への定傾 斜を増しており、左舷に浸水していると推測される。 $\mathrm{S}$ 号は事故前の航海でバラストタンクに海水が浸水 していたが、その後、空気管頭の整備等浸水対策が 講じられていなかった。よって、今回の事故は浸水 防止機能に不具合のある空気管頭から海水が浸水し たと推測される。そこで、波浪中の船体の横摇れ及 び相対水位を計算し、相対水位と空気管頭の位置関 係からバラストタンクへの浸水及びデッキや膨張卜 ランク上の海水の滞留による船体の姿勢等を検討し た。空気管は 1 つのバラストタンクに 2 つ設置され ており、その 2 つの径はそれぞれ $\phi 100 \mathrm{~mm}$ と $\phi 80 \mathrm{~mm}$ である。船体運動計算はストリップ法の一種である Salvesen-Tuck-Faltinsen 法（STF 法）(3)で行った。 このSTF 法は特異点分布法であることから左右非対 称の船型を扱うことが可能である。横摇れ減衰力は 速度影響を考慮した成分分離法 ${ }^{(4)}$ で推定した。

\subsection{1 定傾斜し始めた時の船体運動}

$\mathrm{S}$ 号の出港時の状態で地点 I の海象下を航行した 場合の船体運動の計算結果から相対水位変動を計算 した。この時の船の固有周期は $8.76 \mathrm{sec}$ 、、船速は $11 \mathrm{kn}$ 、海象は斜め追い波 $35 \mathrm{deg}$ 、、波高 $2.22 \mathrm{~m}$ 、波周 
期 $5.3 \mathrm{sec}$ 、、出会い周期 $12.07 \mathrm{sec}$. である。波上側 (左 舷側）の相対水位の計算結果を図 5 に示す。図中、 ○は相対水位を、 $\triangle$ は空気管頭の高さを示す。なお、 S. S. 1.9 にある空気管頭は燃料サービスタンクの空 気管頭である。相対水位は上甲板及び膨張トランク を超え、バラストタンクの空気管頭まで到達してい ることが分かる。

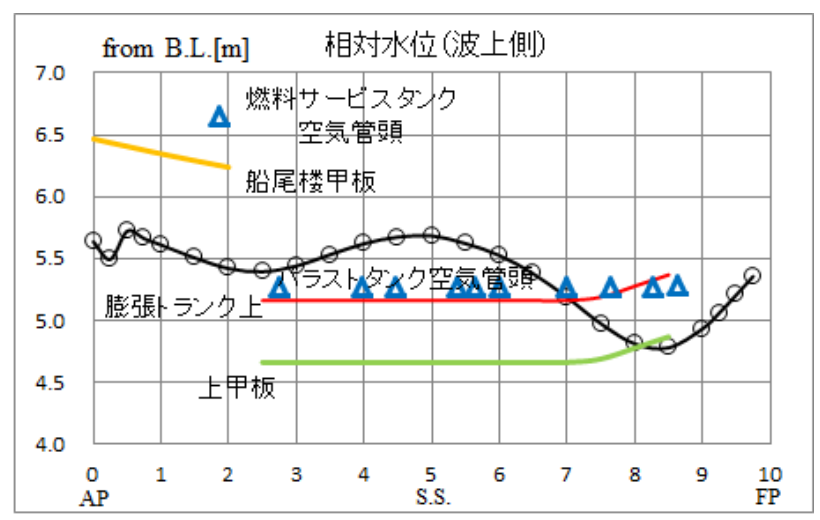

図 5 相対水位計算結果（地点 I 、出港状態）

\subsection{2 地点 I での船体運動}

$\mathrm{S}$ 号は地点 I を航行時には左舷側に約 $4.5 \mathrm{deg}$. 定 傾斜していたと推定される。そこで、3.5.1 で求め た相対水位の計算結果を基に、左舷側に $4.5 \mathrm{deg}$. の 定傾斜した状態になるよう海水が滞留する上甲板上 及び澎張トランク上の海水滞留量約 $24.8 \mathrm{t}$ と、没水 する空気管頭からバラストタンクへの浸水量約 15. $0 \mathrm{t}$ を設定した。バラストタンクへの浸水量設定 については次章で詳細に述べる。この状態で地点 I を斜め追い波 $35 \mathrm{deg}$ 、、船速 $11.0 \mathrm{kn}$ で航行時の運動 計算結果を図 6 に示寸。計算結果は左舷 $4.5 \mathrm{deg}$. を 中心に左舷 $1.2 \mathrm{deg}$. から左舷 7.8deg. の横摇れとな り、事故の経過情報と一致する。この時の波上側（左 舷側）の相対水位の計算結果を図 7 に示寸。波は膨 張トランク上及びバラストタンクの空気管頭まで到 達していることが分かる。

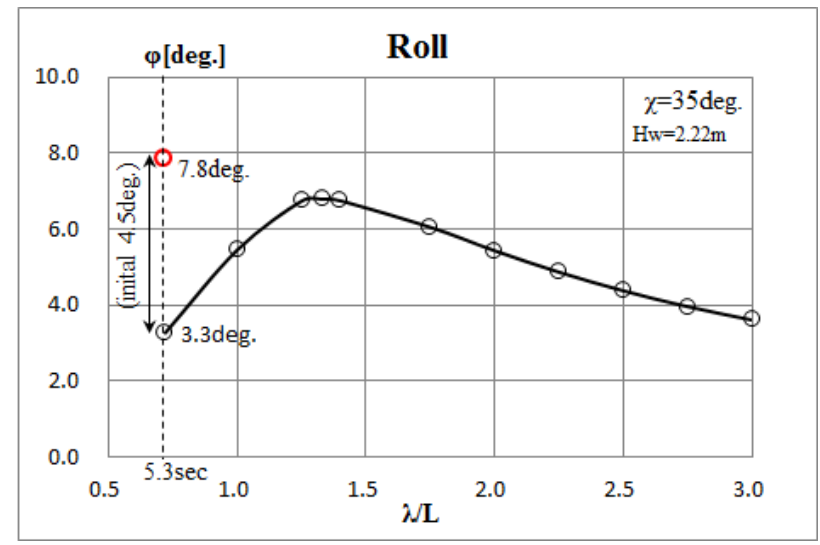

図 6 横摇れ計算結果（地点 I 、定傾斜左 $4.5 \mathrm{deg}$. )

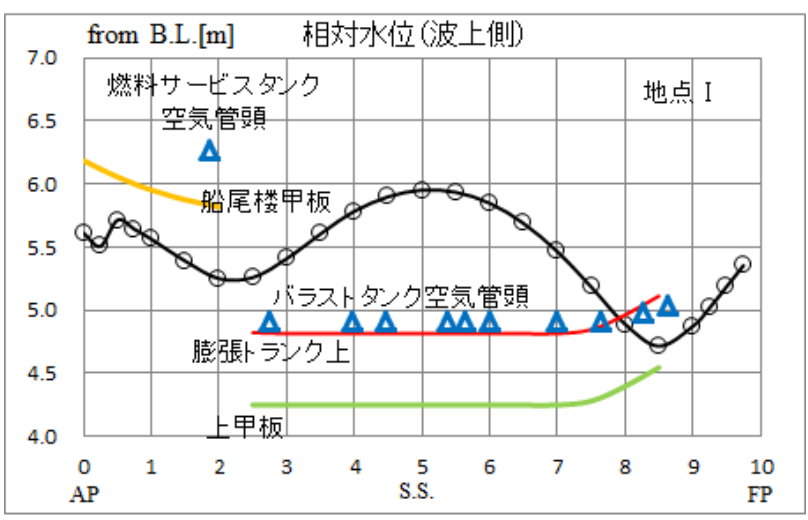

図 7 相対水位計算結果 (地点 I 、定傾斜左 $4.5 \mathrm{deg}$.)

\section{5.3 地点 II での船体運動}

$\mathrm{S}$ 号は地点 II では左舷側に定傾斜を増し、燃料サ ービスタンクの空気管頭まで波が到達していたと推 測される。そこで左舷側に定傾斜 $4.5 \mathrm{deg}$. の状態で 地点 I を航行した場合の相対水位の計算結果 (図 7) を用いて、没水するデッキや膨張トランク上の滞留 水及び空気管頭からバラストタンクへの海水流入を 増加させながら地点 II を航行時の船体運動と相対水 位を計算し、船尾楼甲板にある燃料サービスタンク の空気管頭が没水する状態を求めた。海象は斜め追 い波 $35 \mathrm{deg}$ 、、波高 $2.66 \mathrm{~m}$ 、波周期 $7.2 \mathrm{sec}$ 、、船速 9.8 $\mathrm{kn}$ である。左舷上甲板及び膨張トランク上に約 24.8 $\mathrm{t}$ の海水が滞留し、左舷バラストタンクに約 $17.1 \mathrm{t}$ の海水が浸水していた場合、左舷側への定傾斜は 5. $8 \mathrm{deg}$. 横摇れ運動は左 24. $1 \mathrm{deg}$. から右舷 $12.5 \mathrm{deg}$. の横摇れとなり、相対水位は燃料サービスタンクの 空気管頭に到達した。図 8 に左舷側に定傾斜 $5.8 \mathrm{deg}$. の状態での相対水位の計算結果を示す。

一方、左舷バラストタンクに海水が流入せず定傾 斜がない状態で地点 II を航行した場合の相対水位の 計算結果を図 9 に示寸。波はバラストタンクの空気 
管頭まで到達しないことが分かる。よって、バラス トタンクの空気管頭の浸水防止機能が正常であり、 バラストタンクに浸水がなければ、この海域は安全 に航行できたことになる。

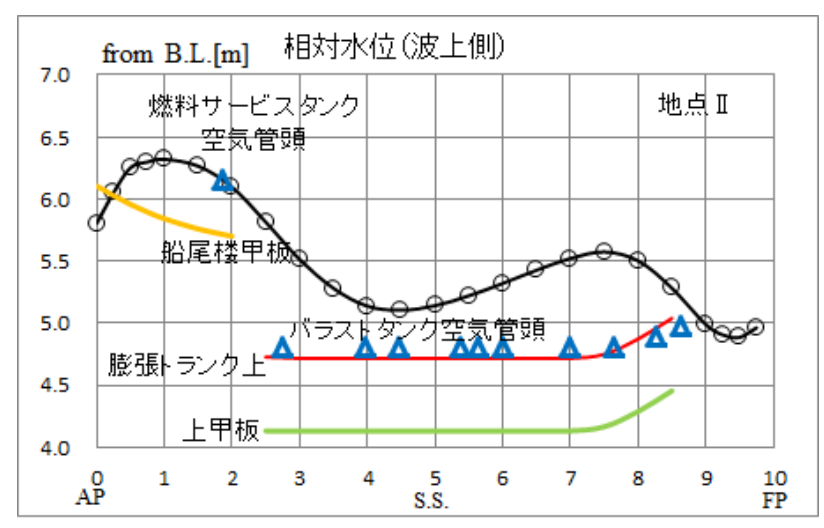

困 8 相対水位計算結果（地点 II 、定傾斜左 $5.8^{\circ}$ ）

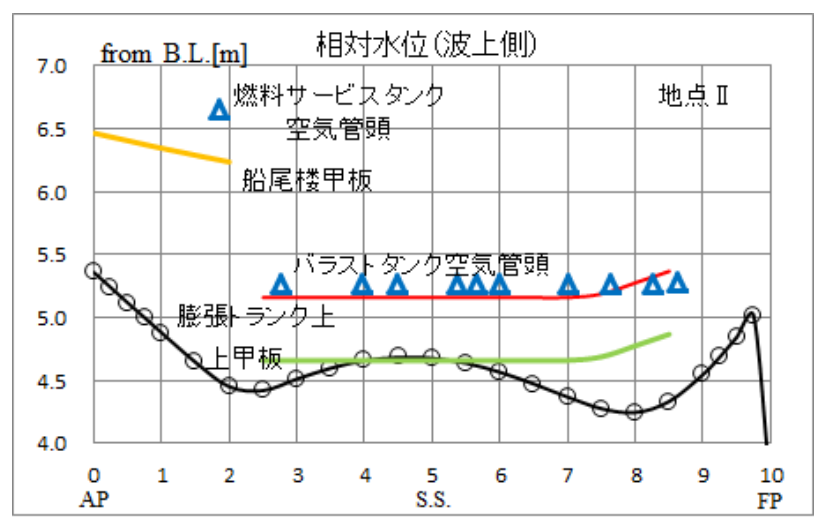

図 9 相対水位計算結果（地点 II 、定傾斜無）

\subsection{4 地点 III、IVでの船の傾斜角}

$\mathrm{S}$ 号は地点III では左舷側への定傾斜が $25 \mathrm{deg}$.にな り、地点IVでは $50 \mathrm{deg}$.まで傾斜して転覆した。左舷 側への定傾斜 $5.8 \mathrm{deg}$. の状態で地点 II を航行した場 合の相対水位の計算結果（図 8）を用いてバラスト タンクへさらに浸水を想定し、転覆直前の定傾斜約 $50 \mathrm{deg}$. が発生しうる状態の復原性計算を行った。

左舷膨張卜ランク上及び左舷船尾楼甲板上に $31.5 \mathrm{t}$ の滞留水と、左舷バラストタンクに $52.1 \mathrm{t}$ の 海水が浸水した場合の実質的な復原力曲線を図 10 中の実線で示す。この時、滞留水及び浸水による左 舷側への傾斜は $16.5 \mathrm{deg}$. であり、20deg. を超えると 最大復原てこを超えてしまい転覆することになる。 復原力がほとんどなくなる状態であったが、船尾楼 甲板上の出入口が閉じられていたことから、船尾楼 甲板上にある甲板室の浮力を加えて計算した。計算
結果を図 10 中の破線で示す。左舷側への定傾斜が約 16. $5 \mathrm{deg}$. から 47.0deg. まで復原てこが $0.0 \mathrm{~m}$ 付近で 一定であり、この範囲のいずれかの傾斜になりえる 状態にあることが分かる。傾斜角が $47.0 \mathrm{deg}$. を超え ると船は転覆する状態であり、事故時の状況と一致 する。

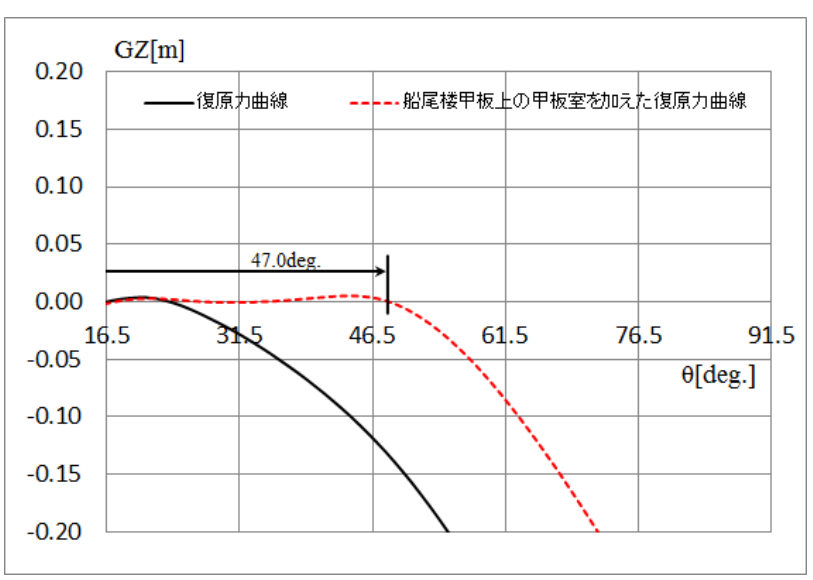

困 10 定傾斜 $16.5 \mathrm{deg}$. の時の復原力曲線

\subsection{5 沈没時の船の状態}

$\mathrm{S}$ 号は転覆後浸水が進み、浮力を喪失して沈没し たと考えられるため、浮力喪失時の浸水状態を検討 した。S 号の復原力計算に考慮している容積分の排 水量は約 2480 t である。

両舷すべてのバラストタンクと清水タンクに浸 水率 0.95 、機関室、舵機室に浸水率 0.85 を乗じた 浸水量約 $750 \mathrm{t}$ を出港時の排水量 $1751.55 \mathrm{t}$ と合わせ ると排水量の合計は約 $2500 t$ になり、浮力を上回っ て沈没に至る結果が得られた。

\section{4. 空気管頭からの浸水の検証}

今回の事故では浸水防止機能に不具合がある空 気管頭からの海水の浸水が事故の発生につながった 推測される。そこで空気管頭没水時の浸水状況を検 証するために実機を用いて実験を行った。

\section{1 実験概要}

使用した管頭金物は S 号に設置されていたディス クフロート式 (径 $100 \mathrm{~mm}$ ) と同型の実機である。困 11 に実験で使用した管頭金物の側面図を示す。没水 時には管頭金物内のディスクフロートが浮上するこ とによりバラストタンクへの海水の浸水を防ぐ構造 である。実験装置は管頭金物下のフランジより塩ビ のフランジで管を繋ぎ、径 $200 \mathrm{~mm}$ の塩ビ管（長さ 
$530 \mathrm{~mm}$ ）をタンクとして模擬したものを製作した。な お、この塩ビ管のタンク上部には水面上に延びた空 気管を設けている。実験装置の外観を図 12 に示寸。

実験では地点 II で左舷側定傾斜 $5.8 \mathrm{deg}$. での相対 水位の計算結果（図 8) にある船首から 3 番目の空 気管頭と波面との関係を再現し、浸水量を計測した。 この時の空気管頭と波との関係を図 13 に示す。管頭 金物下のフランジ部より没水深度 $1.02 \mathrm{~m}$ 、運動周期 4. $2 \mathrm{sec}$.の運動を、実験装置を上下運動させることで 事故当時の状況を再現した。また、ディスクフロー 卜は正常の場合と、ディスクフロートを固定し浸水 防止機能が働かない場合の 2 状態、没水時の空気管 頭の傾斜角は $0 \mathrm{deg}$ 、 $15 \mathrm{deg}$ 、 、30deg.（開口部を下 向き）の 3 状態とした。実験は 2 回繰り返し、1 回 あたりの浸水量はその平均值とした。

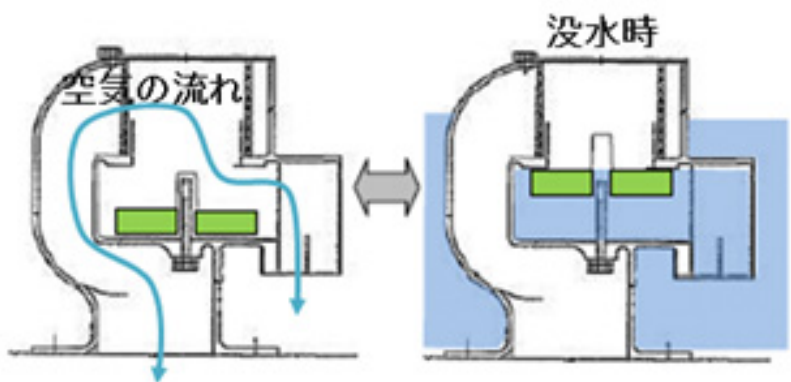

困 11 管頭金物側面図（ディスクフロート式）

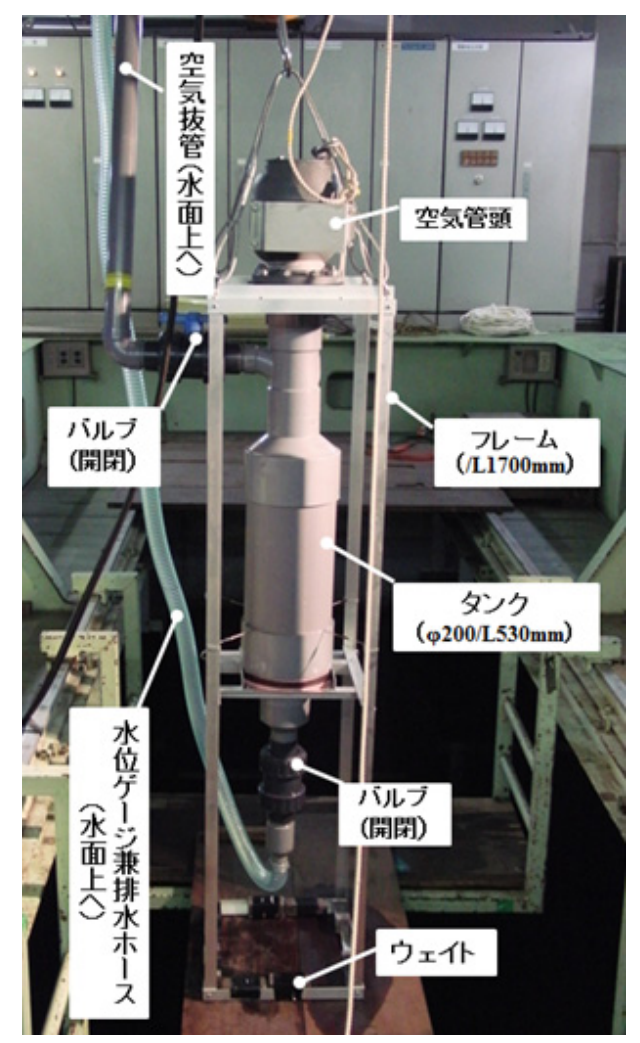

図 12 実験装置の外観

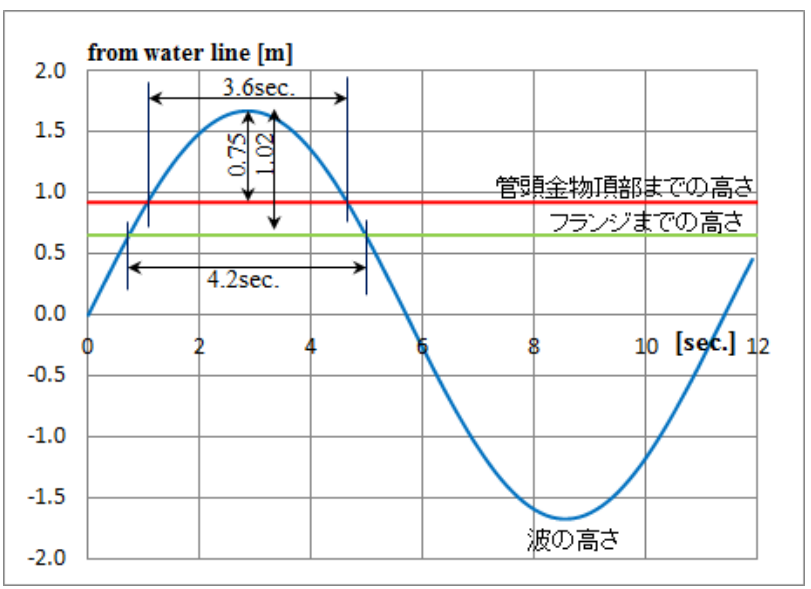

図 13 実験で再現した波と空気管頭の関係（地点 II 、 定傾斜左 5.8deg.)

\section{2 実験結果}

実験結果を表 3 に示す。ディスクフロートが正常 に機能する場合では浸水量は約 $0.2 \sim 0.6 \ell$ 程度と 少量であったが、ディスクフロートを固定した場合、 浸水量は約 16〜20 l になることが分かる。

ここで、タンクの容量は十分に大きく、一回の浸 水で内部の圧力は変化しないとすると、1 周期で空 気管頭から入る浸水量 $\mathrm{Q}_{0}$ を次式とする。

$$
Q_{0}=\int_{t 1}^{t 2} C \frac{D^{2}}{4} \sqrt{2 g\left(h_{w} \sin \frac{2 \pi t}{T_{e}}-h_{a}\right)} d t
$$

ここで C は浸水量係数 0.6、D は開口部の直径、 $\mathrm{h}_{\mathrm{w}}$ は相対水位の最大值、 $h_{a}$ は喫水から管頭部高さ、 $\mathrm{T}_{\mathrm{e}}$ は出会い周期である。

(1) 式で実験状態を計算した場合、浸水量は約 16 l となり、ディスクフロートを固定した場合の実験 結果とほぼ一致することが分かる。

表 3 事故発生状態を想定した浸水実験結果

\begin{tabular}{|c|c|c|}
\hline 傾斜角 $[\mathrm{deg}]$. & 正常状態 $[\ell]$ & 固定状態 $[\ell]$ \\
\hline 0 & 0.56 & 16.46 \\
\hline 10 & 0.47 & 19.54 \\
\hline 15 & 0.21 & 17.86 \\
\hline
\end{tabular}

前章でのバラストタンクへの浸水量設定は、この (1) 式と S 号の相対水位の計算結果を用いて左舷側 の没水する空気管頭から入る浸水量を 1 周期分で計 算し、S 号の出会い波周期と航行時間から推定した 波に出会う回数より管頭金物の浸水防止機能に不具 
合がある場合に十分にあり得る浸水量を設定してい る。事故発生時には S 号のディスクフロートのいく つかは完全には機能していなかったことが推測され る。

\section{5. 再発防止}

本事故の解析により、乾舷が小さく、膨張トラン ク上に波が打ち込む状態で航行する船舶は、上甲板 及び膨張トランク上に波が打込み、海水が滞留して 船体が傾斜し、上甲板上に設置された空気管頭の浸 水防止機能が正常に働かない場合はバラストタンク に海水が浸水することがあることが分かった。今回 の船舶事故を受けて、運輸安全委員会は同じディス クフロート式の空気管頭を設置した他の船舶に対し て空気管頭内部の状態を調查した ${ }^{(1)}$ 。その結果、デ イスクフロートを覆う鋳物内部に厚い錆が生じ、そ の錆によりディスクフロートの動きが制限されて浸 水防止機能が働かない空気管頭があった。そこで、 再発防止策として空気管頭の整備を十分に行うよう 平成 24 年 6 月 29 日に運輸安全委員会より国土交通 大臣に対して意見が提出された。また、同日に国土 交通省海事局より一般社団法人日本船主協会及び日 本内航海運組合総連合会に対して上記意見を会員に 周知するよう通知された。

\section{6. 結言}

本論文では転覆・沈没事故の解析事例として平成 23 年 1 月に転覆・沈没したケミカルタンカーについ て事故発生時の復原性や船の浸水、傾斜状態及び船 体運動を解析した結果を述べた。左斜め追い波中を 航行中、左舷上甲板および膨張トランク上に海水が 打込み、滞留状態が継続し、その滞留水が定傾斜を 生み、さらに左舷バラストタンクの空気管の管頭金 物の浸水防止機能の不具合により左舷バラストタン クへ海水が浸水して左舷側への定傾斜が大きくなり、 この繰り返しが定傾斜を増大させ、転覆して沈没し た状況を示した。また、解析結果より空気管頭の浸 水防止機能の不具合が事故の要因であることから、 再発防止策として空気管頭の整備を実施するよう周 知された。この解析結果と再発防止策により、今後 事故が軽減されることを期待したい。

\section{謝辞}

本研究で実施した空気管頭からの浸水実験を行 うにあたり、海上技術安全研究所流体設計系沢田博 史主任研究員 (研究当時) 及び流体性能評価系塚田 吉昭主任研究員にご協力いただいた。関係各位に深 く感謝の意を表します。

\section{参考文献}

（1）運輸安全委員会：船舶事故調査報告書, MA2012-12， 2012. 12.

（2）藤原敏文, 上野道雄, 池田良穗 : 成分分離型モ デルを利用した新しい風圧力推定法, 日本船舶 海洋工学会論文集第 2 号, pp. 243-255, 2005. 12.

(3) Nils Salvesen, E. 0. Tuck and Odd Faltinsen : Ship Motions and Sea Loads, The Society of Naval Architects and Marine Engineers, pp. 250-288, 1970.

（4）池田良穂: 横摇孔減衰力, 運動性能研究委員会 第 1 回シンポジウム, 日本造船学会, pp. 241-250, 1984. 12. 